\title{
A Japanese Protégé in Pera: Fukuchi Gen'ichirō's Reports on the Mixed Courts of Turkey and Egypt
}

On a spring morning in 1873, two unusual visitors disembarked from a mail steamer and set foot in Istanbul. Now 35 years old, Shimaji Mokurai was a Buddhist priest on a journey that would soon take him on to Palestine, with excursions to Jerusalem and Bethlehem as he explored the roots of Christianity. His companion, Fukuchi Gen'ichirō, was a month short of his $32^{\text {nd }}$ birthday. Now a Meiji government official, he was a veteran traveller who had been to Europe several times before as an interpreter. After several months in Britain and France, they were both making their way back to Japan. Instead of heading straight for Suez before crossing the Indian Ocean, however, they had decided to take a detour first through the eastern Mediterranean, starting with this visit to the capital of the Ottoman Empire. They were the first travellers from Japan ever known to have set foot in Istanbul.

Arriving in the city they knew as Constantinople, Shimaji and Fukuchi landed in a district called Pera on the northern shore of the Golden Horn. On the hill behind the European hotels and embassies close to the waterfront they could see the Galata Tower, marking the site of the Genoese colony once developed here in medieval times. First they stopped by at the customs house, but could not retrieve their luggage until the superintendent arrived, so in the meantime they checked in at the Hotel de France before going out to explore. Shimaji's diary records some of their first impressions. It was a Friday, the Muslim day of prayer, and there were large crowds, reminding him of India, which he had visited earlier on his passage to Europe. Street sellers were everywhere, as in Japan, and Fukuchi passed some time talking with the locals. There were also some European residents or visitors riding through the streets, as horses could be hired for 10 francs, and carriages were available for 30 francs. In Shimaji's view, the local women seemed to disapprove of European couples riding side by side. Dressed in white shawls, they did not get out much, he noted, but some were to be seen travelling by carriage, smoking tobacco as they rode about town, though they did not share their compartments with any men. ${ }^{1}$

Later that day, the two Japanese travellers visited the French Embassy, which Shimaji found extremely grand. ${ }^{2}$ As Fukuchi later recalled, he did 'not feel any confidence in the peculiar laws and customs of Turkey, nor in the administration'. Accordingly, he produced his credentials at the embassy as a

\footnotetext{
${ }^{1}$ Shimaji Mokurai, Kōsei Nissaku, in Shimaji Mokurai Zenshū, vol. 6 (Kyoto: Honganji Shuppan Kyōkai, 1973), 77.

${ }^{2}$ Ibid.
} 
Japanese official, and asked to 'be taken under the protection' of France, 'as the country which the Minister in question represented possessed extraterritorial rights in Turkey. ${ }^{3}$ His request was soon granted, so although not French citizens themselves, Fukuchi and Shimaji now enjoyed the status of protégés, ensuring protection from the French authorities should they be entangled in any dispute during their stay. Fukuchi now turned his attention to his appointed task, to investigate the mixed courts in Turkey and Egypt.

This trip to Istanbul in 1873 was the first sign of Meiji Japan's direct interest in the Ottoman Empire. These two societies had evolved in very different cultural settings and regional contexts, yet now in the increasingly interconnected world of the late nineteenth century, there was a suggestion that the experiences and commonalities they shared might warrant closer inspection. This chapter traces how Fukuchi's research marked the departure point in a dialogue over judicial reform that would appear to draw Meiji Japan closer to the Middle East. It was the onset of Japan's strategic interest in the Mediterranean world.

\section{Modern Japan's Introduction to the Middle East}

By the twentieth century there was a growing perception within Japan of a cultural heritage shared far and wide across Asia. In its broadest conception, this stretched as far west as the Ottoman lands on the shores of the Mediterranean Sea. Writing in 1904 on the theme of 'Asia as One', the art critic Okakura Kakuzō claimed, 'Arab chivalry, Persian poetry, Chinese ethics, and Indian thought, all speak of a single ancient Asiatic peace, in which there grew up a common life, bearing in different regions different characteristic blossoms, but nowhere capable of a hard and fast dividing-line.' This notion of Asia, however, was a relatively recent import to Japan. Originally developed by the Greeks and then the Romans, 'it was, at first, a purely European idea,' only now gaining currency in the course of Meiji Japan's engagement with the Western world. ${ }^{4}$ Nevertheless, it soon had a major impact as Okakura's vision of shared cultural heritage led to perceptions of pan-Asian solidarity which, used to political ends, were manipulated to legitimize a leading role for Japan in a broader campaign against Western hegemony. Meiji Japan became the first state in 'Asia' to introduce a modern constitution in 1889, and also the first to negotiate an end to extraterritorial jurisdiction a decade later. In the early twentieth century it thus served as something of a model for various

\footnotetext{
${ }^{3}$ PRO 30/29/312 - printed for the use of the Foreign Office. July 1881.

${ }^{4}$ Michael Penn, 'East Meets West: An Ottoman Mission in Meiji Japan', in Renée Worringer (eds.), The Islamic Middle East and Japan: Perceptions, Aspirations and the Birth of Intra-Asian Modernity (Princeton: Marcus Weiner Publications, 2007), 45.
} 
independence and nationalist leaders across this vast geographical space, among them Kemal Ataturk, the founder of the Republic of Turkey.

Early Japanese overseas travellers had already noticed some cultural comparisons between their homeland and the Middle East, but the synergies they shared were not necessarily compelling, or immediately obvious. It was during the last years of Tokugawa rule in the 1860s that diplomatic envoys began travelling through Egypt en route to Paris, London, and other capitals in Europe. Until the opening of the Suez Canal in 1869, this involved a journey by train from Suez to Alexandria, with a night or two in Cairo along the way. The first such mission passed through Egypt in 1862; the second in 1864 found time for a trip to nearby Giza, immortalized in a famous portrait captured by Antonio Beato, an Italian photographer, of 34 samurai posing in front of the Sphinx. One Tokugawa official visiting Egypt in 1865 thought that 'many of the natives' customs resemble our own', and other observers found points of comparison in monks' garments, ships and garden design. Although they expressed awe at the antiquity of the Pyramids, however, they were generally unimpressed by the dilapidated state of buildings in Cairo.

Moreover, they expressed little real sense of cultural affinity with the local population, reserving their admiration more for the technological marvels of the railway and telegraph networks built by the Europeans to ferry them across the desert. ${ }^{5}$

Given such ambivalence, or even indifference, what exactly stimulated the subsequent growth of Japanese interest in the Middle East? In hindsight it is easy to find similarities in the commercial relations they shared with the Western powers. As non-Christian states, both Japan and the Ottoman Empire had signed what are now often described as 'unequal' treaties, granting foreign residents, among other privileges, extraterritorial rights that protected them from local courts. In Japan these had taken effect through the Ansei Treaties signed with the United States, Britain, France, Holland and Russia in 1858. In the Ottoman Empire, European residents had enjoyed such privileges for centuries already under the capitulations usually granted by incoming sultans. These had since become formalized through a series of treaties, such as those signed with France and Britain in 1838.

In recent years, extraterritoriality had become a topical issue in international politics as part of the Eastern Question that came to a head the 1850s with the Crimean War. Both Russia and France now projected their interests in the eastern Mediterranean by extending their protection respectively over Greek Orthodox and Catholic subjects of the Ottoman Empire. The British,

\footnotetext{
${ }^{5}$ Andrew Cobbing, The Japanese Discovery of Victorian Britain: Early treavel encounters in the Far West (Folkestone: Japan Library, 1998), 59-60.
} 
meanwhile, had granted passports to large numbers of lonian and Maltese merchants who plied their trade in port cities such as Istanbul and Smyrna (modern-day Izmir). Besides the consular courts that offered protection to such proxy subjects, or protégés, mixed tribunals had also been set up in recent decades as Ottoman and foreign judges presided together over various suits. ${ }^{6}$ In Egypt, meanwhile, the construction of the Suez Canal contributed to the 'judicial chaos' prevailing in multicultural commercial centres such as Alexandria, where the foreign population had risen exponentially in the nineteenth century. ${ }^{7}$ In 1867 this growing problem prompted Egypt's foreign minister, Nūbār Pasha, to propose a new unified system of mixed courts to replace all eighteen consular regimes in civil cases.

This complex judicial landscape appears to have escaped the notice of early Japanese travellers passing through Egypt, but it soon loomed into view for the new Meiji government. Both the Western powers and Japan welcomed the opportunity provided in the Ansei Treaties, on or after 1 July 1872, to make demands for revisions on a year's notice, 'with a view to the insertion therein of such amendments as experience shall prove to be desirable'. ${ }^{8}$ For the British merchants who dominated the foreign community in the treaty ports, this presented a chance to gain access to the interior of Japan. Precedent suggested nothing less, as the first round of treaties with China in the 1840s had only opened ports along the coast, and it was the second round of treaties in the 1850s that then opened access to the Yangzi Basin and river ports deep inland. There was also broad support for the introduction of mixed courts for civil cases. The idea had been suggested already by the British diplomat Ernest Satow in 1866, after foreign businessmen complained that it was impossible to recover debts from native merchants through the Japanese courts. ${ }^{9}$ It was not such a novel plan, however, as such tribunals had existed in the Ottoman Empire for decades, the new proposals for Egypt would soon emerge, and closer to their own experience in East Asia, experiments with mixed courts had been tried in Guangzhou in 1858, and in Shanghai since $1864 .^{10}$

For the Meiji government, meanwhile, treaty revision seemed like an opportunity to reclaim control over tariff rates. Their other key grievance was

\footnotetext{
${ }^{6}$ Turan Kayaoğlu, Legal Imperialism: Extraterritoriality in the Ottoman Empire, China and Japan (Cambridge: Cambridge University Press, 200x), 114-118.

7 Jasper Brinton, The Mixed Courts of Egypt (New Haven: Yale University Press, 1968$), 9$.

${ }^{8}$ Article XXII, Treaty of Yedo. Laurence Oliphant, Narrative of the Earl of Elgin's Mission to China and Japan in the Years 1857, '58' '59 (Edinburgh and London: William Blackwood and Sons, 1859), 469.

9 The Japan Times, 19 May 1866.

${ }^{10}$ Pär Kristoffer Cassel, Grounds of Judgment: Extraterritoriality and Imperial Power in Nineteenth-Century China and Japan (Oxford: Oxford University Press, 2012), 58, 66.
} 
the extraterritorial jurisdiction enshrined in the treaties, which in effect imposed a system of legal imperialism through the consular courts, encroaching on Japan's sovereignty by enforcing the application of foreign laws on Japanese soil. ${ }^{11}$ In previous generations there had been no real stigma attached to traditions of legal pluralism, and patterns of overlapping jurisdiction were not considered so unusual. More recently, however, publications such as Henry Wheaton's Elements of International Law (1837) had fostered the rise of legal positivism, and a growing awareness that extraterritoriality, with its attendant consular courts, was fundamentally incompatible with the inalienable rights of a sovereign state. ${ }^{12}$ When Tokugawa negotiators concluded the Ansei Treaties in 1858, they were simply not aware of these developments in the international legal fraternity. Yet by the time the Meiji government came into power a decade later, several studies and translations in this field were already prompting the realization that the consular courts operating under these treaties would not be tolerated by any of the so-called 'civilized states' the new Japan now wished to emulate. Iwakura Tomomi, a leading figure in the Meiji government, betrayed not just the cultural chauvinism of a court noble raised in Kyoto when, in 1869, he expressed disgust at the presence of foreign troops on Japanese soil - a reference to the French and French regiments stationed at the time in Yokohama. ${ }^{13}$ By including foreign judges in the same category, he also showed some awareness of international law. ${ }^{14}$

The problem was that the treaty powers had no intention of exposing their own nationals to prosecution in Japanese courts for the foreseeable future, if at all. It would simply never happen for so long as such tribunals were suspected of employing the 'barbarous' use of torture still synonymous with allegedly 'despotic' non-Christian regimes stretching from Tokyo to Marrakech. It would take decades of judicial reform, however, before a process of legal institutionalization based on European codes might convince the Western powers that Japan's courts were 'civilized' enough to handle such cases on their own. Aware of this dilemma, in 1871 a report commissioned by Japan's Ministry of Foreign Affairs suggested that mixed courts could be a useful interim arrangement as a stepping stone towards eventually reclaiming full control of court proceedings in Japan.

\footnotetext{
11 The phrase is from Kayaoğlu's Legal Imperialism.

12 Henry Wheaton, Elements of International Law (1836), 98.

${ }^{13}$ French troops had been posted to Yokohama since 1863, British troops since 1864. These foreign regiments finally left in 1875 .

${ }^{14}$ This has been described as 'the intellectual beginning of revision'. Michael Auslin, Negotiating with Imperialism: the unequal treaties and the culture of Japanese diplomacy (Cambridge MA: Harvard University Press, 2004), 157.
} 
Significantly, it was the power of suggestion by Western diplomats that helped Meiji officials to make the make this connection between potential treaty amendments and the proposal for mixed courts now under consideration for Egypt. Several months before, when the Meiji government announced its intention to revise the treaties, the German minister Max von Brandt had mentioned these plans for Egypt in his response. ${ }^{15}$ Similar counsel was offered when a high-profile Japanese embassy led by none other than Iwakura embarked on a global tour at the end of the year to broach the question of treaty revision. The new draft treaty he took with him to the United States incorporated the advice of Erasmus Peshine-Smith, a former US attorney general now working as a legal consultant for the Ministry of Foreign Affairs in Tokyo, who suggested using the Egyptian model to one of the viceambassadors, Itō Hirobumi, shortly before the mission's departure. ${ }^{16}$

These early treaty negotiations with the United States soon petered out, but then in Britain on the next leg of their odyssey, the Japanese ambassadors received some more constructive advice when they visited the Foreign Office in November 1872. During their second interview there, the Foreign Secretary Lord Granville 'referred to the case of Egypt where the extra-territorial jurisdiction had formerly prevailed, but where the experiment was being tried of allowing Egyptian tribunals to administer the law in civil cases. ${ }^{17}$ Such a project was only a modification of the existing system, but it did at least suggest a pathway towards eventual treaty revision. As Granville put it, '[i]f this experiment succeeded, it would be tried in criminal cases also, and there was no reason why a similar course should not be taken with Japan.' The foreign secretary also explained why, for the foreseeable future, extraterritoriality must stay: 'in all such cases the policy of the British Government was to yield [to] the local authorities jurisdiction over British subjects in precise proportion to their advancement in enlightenment and civilization. ${ }^{18}$

Shortly after these talks at the Foreign Office, the Iwakura Embassy moved on to Paris, and there in February 1873 it was decided that Japan needed to

\footnotetext{
${ }^{15}$ Nakaoka San'eki, 'Japanese Research on the Mixed Courts of Egypt in the Earlier Part of the Meiji Period in Connection with the Revision of the 1858 Treaties', Sophia University Repository for Academic Resources, 1988, 31.

${ }^{16}$ Auslin, Negotiating with Imperialism 173.

${ }_{17}$ Memorandum of an Interview between Earl Granville and Iwakura, Chief Japanese Ambassador, at the Foreign Office, 27 November 1872. PRO 881/2138.

$18 \mathrm{lbid}$. Criminal jurisdiction was extended to the mixed courts in Egypt for bankruptcy cases in 1900. A criminal code was in place by the late 1930s to replace consular jurisdiction but remained largely inoperative. Brinton, The Mixed Courts of Egypt, 89, 107, 192.
} 
investigate the systems of mixed courts in the eastern Mediterranean. ${ }^{19}$ The ambassadors clearly took account of Granville's advice, but it was apparently in France that the broader context of this question came into view. According to Frederic Marshall, a British secretary attached to the Japanese legation in Paris, 'it was not until the members of the Embassy reached Europe that they were enabled (especially during their stay in Paris) to study the question thoroughly. They perceived that the Japan Treaties are but another application of the rules and precedents which Europe has employed towards all Eastern Powers since the Capitulations were made with Turkey. ${ }^{20}$ Marshall himself acted as the ambassadors' guide during their stay in Paris and was in a position to guide their thinking. It was no coincidence that the same historical outlook features in an article on 'International Vanities' he wrote for Blackwood's Magazine later that year. In an article on 'Justice Abroad' published in The Quarterly Review in 1874, moreover, he fiercely attacked the system of consular jurisdiction imposed by treaties on states such as the Ottoman Empire and Japan. ${ }^{21}$

The idea of sending a Japanese official to Istanbul, it seems, was put forward by Tanabe Yasukazu, a former Tokugawa official who had served on two diplomatic missions to France, and now as First Secretary in the Ministry of Foreign Affairs, had accompanied the Iwakura Embassy on its travels over the last year. A few days later, the mission was entrusted to Fukuchi Gen'ichirō, another former Tokugawa official who had been with the embassy in America, Britain and France. Like Tanabe, Fukuchi had travelled widely with early Tokugawa delegations, serving as an interpreter on the Takenouchi mission, which had visited Europe in 1862. Three years later, he had been to France and England again in the service of Shibata Takenaka. On that occasion, he was also under instructions to study international law, and following his return translated the English version of de Martens' Guide Diplomatique, which was published in 1869. In his now familiar role as interpreter, moreover, Fukuchi had been present at the recent interview in London when Lord Granville referred Iwakura to the Egyptian model of mixed courts.

\footnotetext{
19 Iwakura Tomomi to Sanjō Sanetomi, 6 February 1873, p.258. Jōyaku kaisei kankei dainihon gaikō bunsho: 1[Diplomatic documents of Japan on treaty revision, vol. 1] (Tokyo, Gaimushō, 1941), 258.

${ }^{20}$ Memorandum by Frederic Marshall, 6 May 1874. Ian Nish (ed.), British Documents on Foreign Affairs: Reports and Papers from the Foreign Office Confidential Print. Part I, From the mid-nineteenth century to the First World War. Series E, Asia, 1860-1914, vol. 1 (Frederick MD: University Publications of America, 1989), 330-331.

${ }^{21}$ Frederic Marshall, 'International Vanities (No. VI Diplomatic Privileges)', Blackwood's Magazine, vol. cxvi (1874), 345-364. Frederick Marshall, 'Justice Abroad', The Fortnightly Review (July 1874), 143-145.
} 


\section{Fukuchi's Travels and Report on Mixed Courts}

After spending two months in Paris, in late February 1873 the Iwakura Embassy set out on the next stage of its tour across Europe, to Belgium, Holland, Germany and then Russia. Later that year, the members of the party also travelled to Austria and visited the Vienna International Exhibition, where they found displays from Japan on show in the 'Oriental Courts'. The exhibits from the Ottoman Empire situated nearby were apparently not so impressive, but it was surely instructive to see how, in European eyes, their land and culture was categorized as 'Asian'. Perhaps it also affected their outlook on international affairs, as through this experience, 'Japanese found themselves sharing a common identity with much of the Islamic world. ${ }^{22}$

Fukuchi, meanwhile, had parted company with the Iwakura Embassy earlier that year, leaving Paris a week before the main party to embark on his journey to the eastern Mediterranean. This was in February 1873, a few days after he received his orders to research the courts in Greece, Turkey and Egypt. Travelling with him was a Buddhist priest called Shimaji Mokurai, who had recently been staying in Europe, and saw this as an opportunity to visit religious sites in the Holy Land before returning to Japan. Fukuchi and Shimaji first made their way overland through Switzerland and Italy, and then by sea from Naples on board a French steamer bound for Athens. Fukuchi met the Greek foreign minister there, and received promises of help but found little real cooperation for his enquiries. Unconvinced that the Greek judicial system had anything much to offer Japan anyway, he and Shimaji decided to continue their journey by sea. Three days after embarking at Piraeus, their ship sailed through the Sea of Marmara and arrived in Istanbul.

Fukuchi had a letter of introduction from the Ottoman ambassador to France, but the foreign minister, Server Pasha, it transpired, was then too busy negotiating with Russia to grant him an audience. He found an opportunity to meet the Russian ambassador, however, who by chance turned out to be an old acquaintance. Nikolai Ignatiev had been in charge of negotiations on the disputed Russo-Japanese border when the Takenouchi mission visited St. Petersburg in 1862, and as a young interpreter in this delegation, Fukuchi had also been involved in these talks. Now eleven years on Istanbul, Ignatiev warned him not to waste his time on studying the Turkish system of mixed courts, which he described as 'unjust and inconvenient', but recommended the Egyptian proposal as a superior model for Japan. Moreover, he arranged an introduction for Fukuchi to meet the Egyptian foreign minister, Nūbār Pasha, who happened to be in Istanbul as well for negotiations with the Ottoman government in the latest round of international talks on his proposal

22 Penn, 'East and West', 46. 
for mixed courts. At various stages these protracted discussions had already taken him to Paris and London, but a further settlement was now required in Istanbul, since the Khedivate of Egypt, although autonomous, was still a tributary state of the Ottoman Empire. ${ }^{23}$

Fukuchi and Shimaji met Nūbār Pasha and his legal advisor on several occasions, receiving some documents with details on the draft charter for mixed courts in Egypt. Between them, they and Ignatiev persuaded Fukuchi that the proposed system for Egypt was the most suitable model if mixed courts were to be introduced in Japan. Besides these talks, the Japanese travellers found time for some leisure, including several trips to the theatre and some excursions as well. At one point they climbed the Galata Tower to enjoy a panoramic view of the city, and through the Russian Embassy they received permission to visit the Topkapi Palace, and the Süleymaniye Mosque. Other visits included Hagia Sophia and a ride by train to see the Rumelian Castle overlooking the Bosphorus. Overall it was an eventful trip: walking through the streets one day they came across 'thousands of troops in line, not allowing us past'; and they even attended a funeral in the chapel at the Russian Embassy. ${ }^{24}$

After staying in Istanbul for nearly two weeks, Fukuchi and Shimaji embarked on the next stage of their journey, a five-day voyage through the eastern Mediterranean. On the way their ship stopped off at ports of call in Smyrna and Rhodes, before reaching Alexandria in Egypt. The Japanese travellers then boarded a Russian ship bound for Palestine, which docked in Jaffa three days later at first light. Following breakfast there at the Hotel London, they took a ride inland by camel to Jerusalem, together with some British and American travellers, and a few days later they visited Bethlehem. Fukuchi and Shimaji spent less than a week in Palestine, but they were the first people from Japan known to have reached the Holy Land. ${ }^{25}$

Embarking again at the port of Jaffa, their Russian ship took them back to Alexandria, from where they travelled on to Cairo. During their eight days in Egypt they visited a bazaar, the Pyramids and a museum, but for Fukuchi at this point the main focus was his research on the judicial system. Next, a train ride to Suez marked the onset of the long journey back to Japan, although the following voyage across the Indian Ocean was staggered to allow time for stays in Bombay, Delhi and Calcutta. For Shimaji this offered a chance to visit

\footnotetext{
${ }^{23}$ Nakaoka San'eki, 'Fukuchi Gen'ichirō no Ejiputo kongō saiban chōsa', Kokusai shōka daigaku ronso, no. 32 (September 1985), 46.

24 Ibid., 80

25 James L. Huffman, Politics of the Meiji Press, The Life of Fukuchi Gen'ichirō (Honolulu: The University Press of Hawaii, 1980), 71.
} 
ancient Buddhist sites, while for Fukuchi the days at sea gave him time to study and translate the documents he had received in Istanbul, and write up notes from his recent investigations in Egypt. ${ }^{26}$ In mid-July they arrived back in Japan, nearly five months after setting out from Paris.

On his first day back at the office in Tokyo, Fukuchi presented a detailed report on mixed courts to the Ministry of Foreign Affairs. This was addressed to Ueno Kagenori, the acting minister in the absence of Soejima Taneomi, who was away in Beijing at the time for negotiations with the Chinese government. Fukuchi's report presented a summary of his research from the time he received his appointment in Paris to his travels in Greece, Turkey and Egypt. He attached two appendices: one a tentative translation of the full text of Nübār Pasha's draft charter; the other, his own views on the merits of adopting the Egyptian model, taking into account the advice of both Ignatiev and Nūbār Pasha. While some modifications would be necessary, Fukuchi recommended introducing mixed courts in Japan. The British seemed intent on such a system anyway, and Fukuchi pointed out that Sydney Locock, the first secretary at the British Embassy in Istanbul, had told him during his visit that Sir Harry Parkes, the British minister in Japan, had asked him for details on the mixed courts in Turkey and Egypt.Given that it seemed impossible to remove consular jurisdiction altogether at this early stage, he considered mixed courts to be 'a lesser evil' for some time to come. ${ }^{27}$

Several factors weighed against the adoption of Fukuchi's recommendation, however. The Ministry of Justice consistently voiced doubts about introducing foreign judges into Japanese courts, claiming that Japan already enjoyed more advantageous terms than those imposed in the Middle East. This impression was reinforced after a Japanese translation was commissioned for James McCoan's newly published 46-page report on Consular Jurisdiction in Turkey and Egypt. The Ministry of Foreign Affairs, moreover, soon decided to shelve its campaign to overhaul extraterritoriality in favour of concentrating on revising tariff rates. Following the return of the Iwakura Embassy later in 1873, there was increasing recognition that the treaty powers would never agree to remove consular jurisdiction until Japan had established a track record on legal reforms, a challenge that would take several years. The Ministry of Finance, meanwhile, also exerted pressure to concentrate on tariffs, as new sources of revenue were needed for a Japanese economy under severe strain following the abolition of the domains in 1871.

By this time Fukuchi had returned to his former post in the Ministry of Finance, but he did not stay there long. In 1874 there was a wave of high-

\footnotetext{
${ }^{26}$ Shimaji, Kōsei nissaku, 82-93.

${ }^{27}$ Nakaoka, 'Ejiputo kongō saiban chōsa' 48
} 
profile government resignations, including that of Kido Takayoshi who both he and Shimaji had looked up to for support. Fukuchi followed suit, abandoning his career as a bureaucrat to accept a post as chief editor of the Nichi-nichi shinbun newspaper instead. Fukuchi was no novice in the field of journalism, having opened and run the Kō kō shinbun [The World] newspaper in Edo (Tokyo) in the last year of the Tokugawa shogunate. During the civil war that brought the new Meiji regime to power, his editorials in support of the failing Tokugawa cause even placed him in danger when Edo fell to the Imperial army, as he was arrested in the summer of 1868 and imprisoned for eight days before friends secured his release. ${ }^{28}$ Now five years on, he would go on to play a key role in raising the profile and influence of the Nichi-nichi, using his contacts in the corridors of power to carry official announcements and projecting an often pro-government message.

According to Nakaoka San'eki, Fukuchi never again expressed any opinion on the Ottoman Empire or Egypt. ${ }^{29}$ In his newspaper editorials, however, he certainly made regular comments on the ongoing issue of treaty revision, writing seventy articles on the subject during the second half of the 1870s, an average of fourteen each year. ${ }^{30}$ These editorials also show that not only did he mention mixed courts but highlighted the common experience that Japan shared with the Ottoman Empire in the guise of commercial treaties and consular jurisdiction. On 'the vital question of extra-territoriality' in 1880, for example, Fukuchi pinpointed why mixed courts were such a topical issue when he asked: 'Shall extra-territoriality be abolished? This would, we think, be far the best course to adopt, but if it is found impracticable to do away with it at once: Shall measures be taken so as to gradually accomplish the same end? This would be pursuing a middle course. ${ }^{31}$

Fukuchi then pointed out to Nichi-nichireaders that both Japan and the Ottoman Empire had experienced the interference of foreign legal regimes in the shape of consular jurisdiction. The summary he gave on the historical origins of the capitulations in the Middle East, moreover, bore a striking resemblance to the rhetoric previously employed by Marshall in his published works on the subject. This similarity, moreover, conceivably bears out Marshall's own claim that it was during their stay in Paris, and probably under his guidance, that the leaders of the Iwakura Embassy first grasped the full range of the issue, prompting them to despatch Fukuchi to Istanbul. As Fukuchi himself explained:

\footnotetext{
${ }^{28}$ Huffman, Politics of the Meiji Press, 59.

${ }^{29}$ Nakaoka, 'Ejiputo kongō saiban chōsa', 51, 55.

${ }^{30}$ Huffman, Politics of the Meiji Press, 122.

31 Inclosure of Nichi-nichi editorial translated in the Japan Times. Kennedy to Granville, 22

February 1880. PRO 30/29/312 - printed for the use of the Foreign Office. July 1881
} 
'It is now a very long time since extra-territoriality was first in force in some parts of the world. We read that when the Turks conquered the Eastern Roman Empire, seizing Constantinople and making it their capital city, they entered into Treaties of amity and commerce with various European nations. The Turks granted permission to the subjects of those nations with whom they made Treaties to reside at a place called Pera, in the vicinity of Constantinople but separated from it by a river. Here then the foreigners established themselves, just as they now do at Yokohama, Nagasaki and other places in Japan. And from that time to the present it has been the rule that the European residents of Pera are governed by their own laws. The example of Turkey has formed the precedent for extra-territoriality, although it is stated that the custom was known in the ancient days of Greece and Rome. ${ }^{32}$

Back in 1862, during the Takenouchi mission's travels across Europe, Fukuchi had once been part of a team of scholars who were under instructions to investigate the state of affairs in each country visited. In the case of Britain, for example, it was noted with a tone of surprise that 'there is no segregation of foreigners into special settlements, so they are all treated in the same way. ${ }^{33}$ Until this time, it would seem, Tokugawa officials had simply not yet realized that designated foreign settlements such as those in treaty ports like Yokohama were, by comparison with Europe, an exception to the norm. It is a measure of just how far Japanese awareness of international affairs had progressed in the years since then that Fukuchi could now draw this connection between treaty ports in Japan and the European quarter in Istanbul. Pera, in short, was the nearest equivalent to a treaty port in Europe.

\section{Subsequent Reports on Mixed Courts}

After several years of preparation, Nūbār Pasha's new system of mixed courts was finally inaugurated in the summer of 1875 . If Egyptian officials were hoping this would provide a mechanism for rolling back foreign interference, however, they would be disappointed. In practice, the system served only to entrench the intervention of foreign judges in local affairs. As Granville once promised, steps were gradually taken to extend the system beyond civil cases, but progress was painfully slow. From 1900 criminal jurisdiction was added to the mixed courts over bankruptcy cases, and by the late 1930s a criminal code was in place to replace consular jurisdiction altogether. This never came into

\footnotetext{
32 Ibid.

33 'Eikoku Tansaku', reproduced in Numata Jirō and Matsuzawa Hiroaki (eds.), Nihon shisō taikei, vol. 66: Seiyō kenbun shū (Tokyo, 1974), 544. Cobbing, The Japanese Discovery of Victorian Britain, 182.
} 
full effect, however, and the system of mixed courts itself remained in operation until 1949, by which time extraterritorial jurisdiction had already been removed practically everywhere else. ${ }^{34}$

In these early years, however, Egypt's new system attracted considerable attention from international legal experts, and more than passing interest from Meiji Japan. Mitsukuri Rinshō, the scholar who probably translated James McCoan's Consular Jurisdiction in Turkey and Egypt in 1873, received further commissions from the Ministry of Justice, translating documents on amendments to the new system in 1875, and an overview of the mixed courts in $1878 .{ }^{35}$ In the summer of 1874 , the year after Fukuchi's report, the Ministry of Public Works also set up a commission on mixed courts at the behest of the new minister, Itō Hirobumi, who in future years became Japan's first cabinet prime minister. Itō also attended some meetings of this committee, which consisted of foreign experts in legal affairs then serving in the Meiji government: Erasmus Peshine-Smith (foreign ministry), J. F. Lowder (head of the Yokohama Customs House), G. W. Hill and George H. Bousquet (justice ministry), besides John R. Davidson, a British legal consultant working for the Ministry of Public Works. ${ }^{36}$

These discussions in Tokyo led to some early diplomatic overtures with the Ottoman Empire. In 1875 the foreign minister, Terashima Munenori, sent a letter to Ueno Kagenori, the Japanese minister in London, instructing him to make contact with his Turkish counterpart, the Ottoman ambassador to Britain. Although the two empires did not yet have commercial relations, he explained, there was enough common ground to justify promoting cordial ties. More specifically, Terashima wanted Ueno to procure a letter of introduction for a Meiji official and conduct a further investigation on mixed courts. ${ }^{37}$ Initial plans to despatch Motono Morimichi, then first secretary in London, did not materialize, but the following year two Meiji diplomats stationed in Europe passed through Istanbul on their way back to Japan. Nakai Hiromu and Watanabe Hiromata, who had been serving in London and Vienna respectively, were received by the Ottoman foreign minister Rashid Pasha

\footnotetext{
${ }^{34}$ Extraterritoriality was removed in Japan in 1899 , Turkey in 1923, Persia in 1927, Siam in 1936, and China in 1943, though it still remained in Tangier and the Gulf States until later in the twentieth century. Brinton, The Mixed Courts of Egypt, 89, 107, 192.

${ }^{35}$ Mitsukuri Rinshō, 'Ejiputo-koku saiban kaisei shorui' (Documents concerning Amendments of the Courts System in Egypt), Ministry of Justice, 1875; Mitsukuri Rinshō, 'Eijiputo hōritsusho: zen' (Complete Egyptian Laws), Ministry of Justice, 1878 (Kokuritsu Kōbunshokan).

${ }^{36}$ John R. Davidson, 'Mixed Courts - Second Report: An Examination of the Question of Japanese Judicial Reform and Codification Viewed in the Light of the Report on the Egyptian System of Mixed Courts dated June 1877' (National Diet Library), 9.

${ }^{37}$ Terashima to Ueno, 22 July 1875. Dainihon gaikō bunsho, vol. 8 [Diplomatic documents of Japan] (Tokyo, Gaimushō, 1938-1940), 42-43.
} 
during their stay. In the same year in Paris, meanwhile, Nūbār Pasha discussed the newly established system of mixed courts in Egypt with Nakano Kenji, the Japanese chargé d'affaires to France. ${ }^{38}$

In the event, it was not a Meiji diplomat but Davidson, the British legal expert now based in Tokyo, who carried out the next round of on-site research. Armed with a letter of introduction arranged in London, in 1877 he travelled to Egypt to hold talks with John Scott, the British judge of the Mixed Court of Appeal, and Sharif Pasha, the Egyptian minister of justice and foreign affairs. ${ }^{39}$ On his return to Japan he presented two reports to the Ministry of Public Works. The first of these submitted in June was simply a factual overview, but the second in August included some analysis on whether Japan should adopt 'the Egyptian system, or a system analogous to the Egyptian system?'40 Davidson was not impressed by all he had seen, commenting that the mixed courts gave away 'too extensive concessions' to the foreign powers, In his view, therefore, 'the adoption of the Egyptian judicial system, surrounded as it is with all these foreign-imposed conditions, would be inconsistent with the dignity of Japan'. ${ }^{41}$ He even criticized 'this Egyptian scheme', quite perceptively given the outcome, as 'almost practically equivalent to establishing in the country a permanent foreign institution under permanent foreign control'. ${ }^{42}$

Despite these reservations, Davidson believed that as long as the necessary modifications were made, a system 'some what analogous to that of Egypt' would 'procure the judicial independence of Japan most surely, and most speedily'. ${ }^{43}$ To contain foreign interference he thought foreign judges should be hired only by the Meiji government. The foreign powers, he pointed out, must have nothing to do with these appointments, which should be arranged instead through independent legal bodies, making them 'agents of Japan just as the Oriental Bank and Mr. [Hugh] Matheson of Lombard street London have been the agents of Japan in the selection of hundreds of other government servants. ${ }^{44}$ Davidson also felt that the arrangements at the end of a five-year trial appeared to be too one-sided, as 'the foreign powers can practically do what they please at the end of the quinquennial period'. At the end of such a probation period, he stressed, the Meiji government should also have the power to stipulate a return to consular jurisdiction if the expected

\footnotetext{
38 Nakaoka, 'Japanese Research on the Mixed Courts of Egypt', 40.

39 Nakaoka, 'Ejiputo kongō saiban chōsa', 56.

40 Davidson, 'Mixed Courts - Second Report', 1-2.

41 lbid., 4.

42 Ibid., 5.

43 Ibid., 6.

44 Ibid., 7.
} 
benefits failed to materialize. ${ }^{45}$ This second report then concluded with a detailed 20-point programme for implementing mixed courts in Japan. While based on the recommendations of the 1874 commission, Davidson now included his own detailed commentary, 'suggesting alterations and additions', together with 'a large number of additional provisions' so as 'to render the scheme complete'. ${ }^{46}$

Further links were being forged between Meiji Japan and the Ottoman Empire at this time. A singular example was the visit to Istanbul of the Seiki, the first battleship in the Japanese Imperial Navy to be built in a domestic shipyard by the Meiji government. In 1878 she was in the Mediterranean as part of a naval training exercise involving, for a Japanese vessel, a pioneering voyage to Europe and back. The Sublime Porte permitted the Seikito dock in Istanbul, and her captain Inoue Yoshika received an audience with the Sultan Abdülhamid II during a twelve-day stay. ${ }^{47}$ Then in $1880-1$, Yoshida Harufumi, a foreign ministry official, led a ten-man delegation that travelled through Persia and the Ottoman Empire to explore the potential for cultivating commercial relations. ${ }^{48}$

In the 1880 s, meanwhile, the question of mixed courts remained topical in Japan, as the new foreign minister Inoue Kaoru orchestrated two multilateral conferences on treaty revision in Tokyo. In 1886 a judge called Hasegawa Takashi suggested conducting further research on Egypt's mixed courts during his voyage back to Japan after attending the International Conference for the Compilation of Commercial Codes in Belgium. Unlike Fukuchi or Davidson, Hasegawa had spent several years handling cases in Kobe and then as president of the Yokohama Court, so he brought to the enquiry first-hand experience of judicial cases involving foreigners. In January 1887 he spent two weeks in Egypt, interviewing Nūbār Pasha, who was now prime minister as well as minister of both foreign affairs and justice. Apart from two defects, his host seemed content with the progress of the Egyptian experiment. He was less than satisfied, however, with the same lack of control over appointing foreign judges that Davidson had mentioned a decade before. He also complained of the foreign powers' apparent reluctance to introduce amendments in recognition of Egypt's recent development, despite the rhetoric by diplomats like Granville on ceding jurisdiction to local courts in due course. ${ }^{49}$

\footnotetext{
45 lbid., 8.

46 Ibid., 9-59.

${ }^{47}$ Selcuk Esenbel, 'Japanese Perspectives of the Ottoman World' in Selcuk Esenbel and Inaba Chiharu, The Rising Sun and the Turkish Crescent: New Perspectives on the History of Japanese-Turkish Relations (Istanbul: Bogazici University Press, 2003), 16.

${ }^{48}$ Renée Worringer, Ottomans Imagining Japan: East, Middle East, and non-western modernity at the turn of the twentieth century (Basingstoke: Palgrave Macmillan, 2014), 84.

${ }^{49}$ Nakaoka, 'Japanese Research on the Mixed Courts of Egypt', 39-40.
} 
On returning to Japan the following month, Hasegawa submitted his own detailed report on the mixed courts to the justice minister, Yamada Akiyoshi. ${ }^{50}$ This expressed some reservations about the situation in Egypt, such as the 'Tower of Babel' effect of judges from various countries speaking so many different languages, and the bias of foreign judges who tended to favour their own country's interests. He also took note of an opinion voiced by Friedrich de Martens, the judge of the Mixed Court of Appeal in Egypt, who was dissatisfied with the varying competence of judges appointed by so many different foreign powers. ${ }^{51}$

Hasegawa's report was timely because, in October 1886 while he was still away in Europe, an Anglo-German plan that included mixed courts had been proposed to the second conference on treaty revision then being held in Tokyo. After several months of discussion, Inoue Kaoru even agreed to a revised treaty draft based on this plan the following spring. Besides Hasegawa's report, however, reservations were soon raised by French legal advisor Gustave Boissonade, who in June submitted his written objections to the introduction of foreign judges in Japanese courts. Public indignation over this prospect followed after Boissonade's views were leaked, and the agriculture and commerce minister, Tani Tateki, resigned in protest. Such was the strength of popular feeling that Inoue was forced out of office by September.

Ultimately, the Meiji foreign policy agenda of treaty revision, which had promised to draw Japan and the Ottoman world closer together, would inhibit the development of closer relations. Despite some diplomatic overtures since the 1870s, a formal treaty was never signed. In 1881 during Yoshida Harufumi's visit to Istanbul, the Ottoman foreign minister had shown some receptivity to a bilateral treaty on equal terms. Yet the Meiji government always insisted on capitulations to protect Japanese subjects in Ottoman lands, just as the French Embassy had protected Fukuchi in 1873. At the same time there were some notable expressions of goodwill and ceremonial gestures, such as Imperial Prince Komatsu Akihito's visit to Istanbul in 1887, the same year that Hasegawa compiled his report on Egypt. Three years later the compliment was repaid when the Ertugrrul, an aged frigate in the Ottoman navy, made the long voyage to Japan and docked for a month and a half at Yokohama. Her captain, Osman Pasha, made a round of courtesy calls in nearby Tokyo, but tragedy struck when cholera broke out on board, killing 36 of the crew. Still worse, just a day after embarking on the voyage home, the

\footnotetext{
${ }^{50}$ Transcript of Hasegawa Takashi, The Report on the Realities and Practices of the Mixed Courts of Egypt, Constitutional History Materials Room, National Diet Library, Tokyo.

${ }^{51}$ Nakaoka, 'Japanese Research on the Mixed Courts of Egypt', 39, 42.
} 
Ertuğrul sank in a heavy storm off the Wakayama coast, with the loss of more than 500 men, including Osman Pasha. The 69 Ottoman survivors were taken back on two Japanese warships, the Hiei and the Kongō, reaching Istanbul by the end of $1890 .^{52}$ In an editorial for the Nichi nichi announcing the arrival of the Ertugr ru/mission the previous year, Fukuchi had again focused on the experience both empires shared due to the 'overbearing system of extraterritoriality' enforced by the Western powers. ${ }^{53}$ Yet his own sympathetic outlook on the struggles of the Ottoman Empire was always framed within the context of Japan's own quest for sovereignty. Some Meiji intellectuals had begun discussing the theme of friendship across Asia, as far as Ottoman lands, but in the realm of international politics the challenges of overcoming legal imperialism still kept these empires apart.

52 Penn, 'East meets East', 34-39.

53 Ibid., 47. 